\title{
Gondolatok a világhírú módszer kialakulásáról és alapítójáról, Pető Andrásról, a Semmelweis Egyetem új karának megalakulása kapcsán
}

2017. augusztus 1-tôl a nemzetközi hírű Pető Intézet a Semmelweis Egyetem új kara, a Pető András Kar (PAK) lett. Hosszú utat futottak be, nagy viszontagságokkal, de töretlen munkával és elkötelezettséggel az utódok éppúgy, mint e módszer megalapítója, Pető András. Mozgalmas élete, fantasztikus hite és kitartása nagy eredményeket hozott a mozgásukban sérült gyermekek rehabilitációjában, módszerének különlegességével és különcségével. A kezdetekkor az orvostársadalom kivetette magából, nem találta elég tudományosnak e módszert, persze Pető szakírói tevékenységének nagyfokú hiánya és modora sem segített az elfogadáshoz. Azóta 70 év telt el, s most végre a megfelelő helyén van a gyógyító-nevelő módszerre épülő hungarikum. Ma már 28 nemzetközi, Pető-féle konduktív pedagógiai intézet vagy centrum múködik a világban. Ahhoz, hogy megértsük Pető öszszetett egyéniségét, nemcsak szakma-, de művelődéstörténeti közegbe is kell őt helyeznünk.

\section{Pető Andrásról}

A huszadik század egyik legösszetettebb, legsokoldalúbb, legmúveltebb magyar és nemzetközi orvos gondolkodó s egyben gyógyító alakja Pető András volt. Mint általában, a társadalom legnagyobb része értetlenül áll egy olyan személyiség előtt, mint amilyen Pető András volt, aki többféle tudományban, szakterületen rendelkezett kiváló jártassággal, átlépve az emberek által szabott szakmaterületek határait: remek szépíró, elmélyedt a filozófiában, filoszos gondolkodásmódú, ugyanakkor pszichológiai jártassággal és hozzá nagy szakmai tudással rendelkező alapos és részletes megfigyelő, emberismerő volt, az orvosi tevékenységek, szakmák között több területen kiváló, európai múveltségű, konstruktív, összegző elme. Végtelen kreativitással, élénk lényeglátással minden tudásanyagát felhasználta a megszokott szakmai határokat átlépve szintetizáló, integráló, nyitott, érdeklődő személyisége, aki egyaránt otthon volt Bécsben, Párizsban és Budapesten.
Hallgatta Freud előadásait, az európai irodalom alapos ismerője volt, a bécsi irodalmi életben otthonosan mozgott. Mindent jól és alaposan tudott, ismert és megfigyelt. Mások tudatlansága ingerültté tette, így szokatlan viselkedését sokan kellemetlennek vélték. Különösen az orvostársadalom a maga szögletes, konzervatív, olykor modoros magatartásával viselte nehezen nyers, lényegre törő, egyenes szavait, s természetesen új módszerét, a konduktív gyógyító módszert kivetette magából pont úgy, mint a hasonló viselkedésű Semmelweist egy évszázaddal azelőtt. Egyikük sem viselte el környezetük értetlenségét, a szakmai vezetés és kollégák szűkre szabott határait. Ugyanakkor az elit értelmiség számon tartotta, érdekesnek és különcnek találta, betegei szentnek, csodadoktornak, kollégái és munkatársai karizmatikusnak, ellenségei megszállottnak és kóklernek vagy kuruzslónak tartották.

Pető András életéről és tevékenységéről kevés írásos anyag maradt fenn: önéletrajza, néhány cikke, pár közleménye, a korabeli sajtó, fóleg kortársak, kollégák, barátok és betegek visszaemlékezései csupán. Legközelebbi munkatársa és utódja, Hári Mária írt róla, a módszerről és az intézet nem egyszerü sorsáról [1].

A fentieken kívül abban a szerencsében volt részem, hogy „időben”, 1991-92-ben a még élő kortársak, ismerősök vallomásait magnószalagra rögzíthettem, amelyekből később egy angol nyelvü monográfia lett a frankfurti könyvvásár 1999-es bemutatóján. Ezekből a forrásokból bontakozott ki számomra az a karizmatikus, ugyanakkor a maga küzdelmében gyakran esendő hús-vér Pető András, aki egy rendhagyó világban, rendhagyó emberként élt és dolgozott [2].

\section{Néhány biográfiai adat}

Pető András 1893. szeptember 11-én, Szombathelyen született. Tehetséges, élénk agyú tanuló volt. Szülei szegényesen éltek, ezért tanulás mellett óraadásból fedezte tanulmányai költségeit. „Keresetem egy részét hazaküld- 
tem szüleimnek, akiknek két lényegesen fiatalabb öcsémrōl is gondoskodniuk kellett” - írja önéletrajzában. Elemi iskoláit Szombathelyen végezte, 1911-ben érettségizett Budapesten. Jó íráskészséggel rendelkezett, a Pester Lloydnál, az időszaki német nyelvű pesti újságnál helyezkedett el. Cikkei nyomán a kiadó felfigyelt rá, és ösztöndíjat biztosítva Bécsbe küldte bölcsészetet tanulni. Bécsben viszont a medicinát választotta.

A döntés okáról tôle nincs információnk, önéletrajzában csupán annyit mond erről, hogy Bécsben orvosi diplomát szerzett (1921. július 26.). Örök barátságot kötött egyetemi évei alatt Jakob L. Morenóval (1889-1974): diákéveik alatt együtt laktak, szabadidejüket a bécsi csellengő és koldus gyerekekkel való foglalkozással töltötték, majd később jobbító szándékkal a prostituáltakkal kezdték kidolgozni és kipróbálni a spontaneitás-színházat (Stegreiftheater), a ma már nélkülözhetetlen pszichodráma kezdeti kialakításának módszerét [3], mely a kreativitásra, akcióelvre, cselekvésközpontú csoportterápiára épít $[1,4]$. Moreno Amerikába érkezve egész életét a pszichodráma elméleti kidolgozására és gyakorlati megvalósítására tette fel. Pető késóbb alkalmazta a csoportban megtanult-megtanított, cselekvésbe ágyazott kognitív és emocionális szinten tudatosított, testi-fizikai szintú átéléssel múködő terápiás munkát önismeret-fejlesztésében, szervezetfejlesztésben, közösségformálásban az oktatás során, részben fizikai gyakorlásban, a hozzá kapcsolódó verbális és preverbális szintű terápiával együtt. Egy 2010-ben elhangzott előadás alapján megjelent kötetben olvashatjuk, mi történik a Pető Intézet színjátszó körében: „...kisebb olvasmányrészlet dramatizálása ... megerősíti az olvasmányélményt, erősíti az önkifejezést, a kommunikációs biztonságot, a beleérző képességet, az együttmúködési készségeket, az önkontrollt, miközben fejleszti a testi és térbeli tájékozódást, a különböző helyzet- és helyváltoztatások gyors, lendületes tanulását, a vizuális és halláspercepciót, ... (a díszletkészítés, amely elősegíti, hogy) fejlődjön a tapintás-érzékelés, valamint a kézügyesség, esetleg hangokat, zenét keresnek a jelenethez, újabb érzékelési területeket vonva be ezzel a fejlesztésbe. Az együtt előkészített, majd előadott darab az együttes szereplés és a sikeres mozgás élményét adja a tanulók számára, miközben megvalósul a konduktív pedagógia legfőbb célkitűzése, a tevékenységközpontú, rendszerbe foglalt, komplex - testi, szellemi, érzelmi, erkölcsi, pszichés és szociális - fejlődést elősegítő aktív tanulás" [5].

Azt tudjuk, hogy a századelőn a tudomány és múvészet európai kultúrfővárosának számító Bécs izgalmas, pezsgő, intellektuális légköre nagy hatással lehetett a fiatal Petőre, különösen Freud, akinek az óráira nem csak medikusok jártak. A tanterem zsúfolásig megtelt minden alkalommal, eseményszámba mentek ezek az elméleti és gyakran betegbemutatóval megtartott órák. Freud a párizsi Jean-Martin Charcot (1825-1893) francia neurológus és kórélettani professzornál hallgatott egy félévet. Charcot, a hisztéria apostola jól koreografált előadásain az úgynevezett bemutatót a Salpêtrière-kórház amfiteátrumában tartotta, mely részévé vált a teatrum mundinak - az Európa-híres keddi „leçons du mardi” betegbemutatásokon a hisztéria újfajta vivisectióját demonstrálta a hipnózis módszerével, magával ragadó előadói készséggel. Charcot mint a hisztéria, hipnózis, epilepszia „Napóleonja” nagy hatással volt tanítványára, Freudra, akinek Charcot-hoz füződő rajongó kapcsolata további kutatásainak témájában jelentős helyet foglalt el [6]. A bécsi egyetem híres neurológiai és pszichiátriai kiválóságai, tudásanyaga, Julius Wagner-Jauregg (1927: Nobeldíj) tanítványai, Otto Pötzl, Wilhelm Stekel alaposan felkészítették az ott végző diákokat pszichiátriai szemléleti jártasságban. Így Pető már egyetemi évei alatt komoly pszichiátriai és neurológiai tudásra tett szert, amelyet később továbbfejlesztett. 1919-21-ben WagnerJauregg Neurológiai és Pszichiátriai Klinikáján dolgozik mint elmeorvos.

Bécs a századfordulói és az új századi modern gondolkodás, tudományok és múvészetek fellegvára, az európai értelmiség találkozóhelye, szakmai múhelyek színtere. Robert Musil szerint a modernség fővárosa, a világvége kísérleti telepe, a bomlás virága vagy egyszerúen „requiem és születés” helyszíne. Európa legfiatalabb birodalma megroppant, utolsó évtizedeit élte, haldoklása új eszméknek adott teret. Musil találóan fogalmaz, amikor azt mondja: „Európa olajsima szelleméből hirtelen szárnyat adó láz csapott fel, nem volt megmondható új mûvészet-erkölcs lesz-e belőle, vagy csupán átrétegeződés. Mindenki a régi ellen kívánt küzdeni. A gyakorlatias és a szellemi vállalkozókedv találkozott össze, vagy tért el végletesen egymástól. Tehetségek fejlődtek ki, amelyek régebben megfulladtak volna a közéletben. Hódított a felsőbbrendû és egyidejûleg az alsóbbrendû ember imádata, imádták az egészséget és napfényt, de a törékenységet is, hívők voltak, és szkeptikusok, kastélyparkról és prériről ábrándoztak, társadalmi egyenlőségről és a régi rend szétzúzásáról beszéltek" [7].

Pető sokféle gyakorló orvosi tevékenységet végzett, mindezek mellett orvos íróként, szerkesztőként, filozófusként, gondolkodóként megjárta a belső útjait. Kalandos életét néhány egyszerü mondatban önvallomásában fogalmazza meg. Bárhol volt is, a maximumot nyújtotta, megtanulta és továbbfejlesztette tudásanyagát. Nagyszerü összegző agyában minden információt összekötött, és azt magasabb szintre emelte. Így jöhetett létre az általa megalkotott kezelési módszer, amelynek pontos szakmai behatárolása nagyon nehéz, mert az úgynevezett akadémiai klasszifikációs skatulyák nem olyan rugalmasak, mint Pető összegző gondolkodása. A célt határozta meg, és hozzá többféle tudományág mesterségesen elhatárolt módszereit dolgozta össze.

Vonatkozik ez a helyes levegővételre, az agy és az izmok megfelelő oxigénellátására, az izmok ritmusos mozgatására, a komoly agyi folyamatokra, a szuggesztív életfilozófiára, hogy igenis mindenki meg tudja tenni nemcsak azt, amit tud korlátolt lehetőségei között, ha- 
nem annál sokkal többet: belső 'drive' akaratával és pozitív életszemlélettel bevonva környezetét, nem feladatként, hanem életének szerves részeként. Ezeknek lehet mindenféle aktuális tudományos meghatározásokat adni - ma már mondhatjuk azt is, 'önszabályozás' (self-regulation), 'önmenedzselés' (self-management), 'önkontroll' (self-control), 'önmegváltoztatás' (self-change) és 'önirányított viselkedés' (self-directed behavior) az agyban és az izomcsoportokban speciális, úgynevezett Petőmódszerrel. A lényege, hogy az élet részeként kell kezelnie és akarnia annak, aki ebben a helyzetben van, tehát nem a páciens nélkül helyette, a feje felett, érte, neki, hanem vele együtt az ő akaratával és teljesítményével együtt.

„Bennem sokan csalódtak. Egyesek azt várták tőlem, hogy kiváló matematikus leszek. Egyesek egy eljövendö nagy magyar költöt láttak bennem, egyesek azt hitték, hogy megmaradok a Pester Lloydnál és német nyelvü ujságíró leszek Budapesten.

Mások egy feltörö német nyelvü költöcsillagnak tartottak. Mások azt hitték, hogy a tüdögyógyászat fénye leszek. Két hirneves bécsi klinika hivott meg tanársegédnek. Az Élettani Intézet ki is nevezett tanársegédnek. Semmi nem lettem. Ellenben kalandot kalandra, szenvedést szenvedésre, örömet örömre halmozva éltem, sokszor azt sem tudva, miből. Ha nagyon megégetett a sors, sebeim gyógyulásáig be-bevonultam egy-egy intézetbe, tüdögyógyintézetekbe, fizikoterápiás intézetekbe, elmegyógyintézetbe szegödtem el mint orvos. Késóbb orvos-iró lettem, orvosi folyóirat szerkesztó, orvosi könyvkiadó vezetöje. Kisipari vállalkozásokat többször kezdeményeztem Bécsben, Párizsban, sốt Budapesten is! Párizsban éppen egy orvosi és tudományos könyomatos nyomdát alapitottam, amikor kitört a háború. Egy barátom és felesége kérésére jöttem el Budapestre és belesodródtam a mozgásos kezelésbe. Hirneves lettem, s mint gyógytornatanár fizettem adót. A báború után egyik gyógyult betegem bekényszeritett a Gyógypedagógiai Föiskolára, és innen indult ki, sok nehézség leküzdése után az az intézet...”[2].

\section{A kezdetek}

Pető látszólag logika nélkül vállalt különböző szakterületeken orvosi munkát, de mindig hirtelen váltott, ami arra volt jó, hogy sokféle szemléletet, gyógymódot ismerhetett meg. Elkötelezett közvetlenül a háború előtt és alatt lett, ahol ez a fajta segítség nemcsak fizikális: diagnózis és terápiás módszerére volt szükség, hanem a betegségek mellett a pszichével is aktívan kellett foglalkozni, melyet a gyógymód részévé tett. Pető, mivel Stekel (Freud korai követőinek egyike) elméletéhez közel állt, teóriái közül követhetett néhányat módszerének kidolgozásában: Stekel - aki szerint: „minden gyermekben egy kreatív müvész lészen” [8], valamint a gyógyító gyakorlatiasság és a kutatás szabadsága fontos alapja a tudományának [9] gondolatiságával Pető egyetértett [10].

\section{A konduktív pedagógia rendszerének alapjai}

A Pető által létrehozott gyógyítási módszer lényege, hogy konduktív nevelés alkalmazásával a diszfunkciót ortofunkcióvá alakítsa. Ez így leírva egyszerü, de az út, a módszer, amellyel mindezt el lehet érni, teljes figyelmet, sok türelmet, kitartást és állandó tréninget jelent. A nevelési rendszer alapgondolata, hogy a központi idegrendszer, egyes részeinek károsodása ellenére, rendelkezik olyan tartalékokkal, neuroplaszticitással, amelyek tanulási folyamat következtében a sérült részek funkcióit átveszik, és új kapcsolatok, reflexek kiépítése jöhet létre [11].

Ebben a pedagógiai módszerben a nevelés alanyát arra készteti, hogy aktivizálja önmagát a nevelési folyamat résztvevőjeként, s az önszabályozó tanulás eredményeként egyre önállóbbá váljon. A segítséget és az irányítást a konduktor végzi. A mozgássérültek esetében „nem funkciók speciális gyógyító terápiájával foglalkozik, hanem a lehetséges koordinált múködést alakítja ki” [12]. A konduktív pedagógia egy módszer, amely nem egyes izmokat vagy végtagokat kezel, hanem a corticalis funkciókat cselekménnyé aktualizálja (alakítja át) [13].

A módszer egyes elemei már régebben ismertek voltak, egy hosszú fejlődési folyamat eredménye, de a rendszerbe foglalás és elnevezés Pető érdeme.

Gegesi Kiss Pál akadémikus-rektor em. a következő módon jellemzi e módszer kialakulásának körülményeit [2]: „Pető meggyőződött róla, hogy ezzel a problémával érdemes foglalkozni, fontos probléma, mert a klinikum tehetetlen ezekkel a betegekkel, kizárólag tüneti kezelésben részesítjük őket, tehát érdemes felépíteni egy olyan intézetet, ahol ki lehet dolgozni egy másik szisztémát, s a gyakorlatban alkalmazni, aztán tanítványokat lehet szerezni, és amint látható, világhírúvé is lehet válni. Mert én azt hiszem, hogy Ô az. Persze segítség kellett ahhoz, hogy intézete létrejöjjön és múködjön. Gazdaságilag, politikailag, társadalmilag. Úgy, ahogy én szellemileg támogattam, és lehetőséget adtam, politikailag Ortutayra (Ortutay Gyula, 1910-1978, politikus, néprajzkutató, vallás és közoktatásügyi miniszter), később Biszkura (Biszku Béla, 1921-2016, politikus, belügyminiszter, miniszterelnök-helyettes) támaszkodott. - Ortutay Gyula, jó barátaim közé tartozott, megvolt vele a szellemi kapcsolatom, kultuszminiszter, később akadémikus volt. Biszku viszont nagy erőt képviselt a vezető pártban. Pető nagyon nehéz munkájához fanatizmus kellett. Elég erőszakos ember vagyok én is, talán hallotta, de ő a saját területén szinte agresszív volt. Én természetesnek tartottam, hogy Pető hozzám fordult. Nemcsak azért, mert tekintélyem volt, hanem mert a koncepcióval és annak a gyakorlati megoldásával egyetértettem olyan kórképeknél, ahol úgy látszott, hogy eddig kizárólag ortopéd megoldást javasoltak a mozgászavarokra. Petőék ezeket a problémákat személyiségen keresztül próbálták megoldani: a gyerekkel való pszichés foglalkozással. 
Ha most bemegy abba az intézetbe, látni fogja, hogy a konduktor hogyan igyekszik megnyerni a gyereket közös munkával és szeretettel, s ezért viszonzásként a gyerek milyen erőfeszítést tesz, hogy a konduktor meg legyen vele elégedve. Ez a mechanizmus képes megszüntetni bizonyos inaktivitási atrófiának nevezett (tehát nem mozgásszervi, ezek sorvadások) hátrányt, következésképpen a teljes személyiséget átépíti. Ez a lényege az ő technikájának. Hiszen ahhoz technika is kell, hogy hogyan tudja megmozgatni azt a néhány hónapos csecsemőt, vagy amelyik már járni tanul, és amelyik teljes bénulásos állapotban van" $[2,14]$.

A Pető Intézetben anatómiát oktató Tomcsik Miklós dr. (a Semmelweis Egyetem Társadalomorvostani Intézetének volt munkatársa) így látta a módszer előnyeit és újszerűségét: „Petőből annyit értettem meg, hogy egy furcsa pszichológiai és pedagógiai képzési kombinációt hozott létre. Szerintem az volt Petőnél az óriási megoldás, hogy a gyógyítást és a nevelést egyszerre alkalmazta. Én mint anatómus ezt láttam. A konduktoroknak az anatómiai és az idegrendszeri ismeretekre azért van szükségük, mert tudniuk kell, hogy ha nem múködik együtt egy izomcsoport, annak centrális vagy perifériás oka van, vagy gerincsérülésről van szó. Pető módszerében még az a nagyszerú, hogy többoldali megerôsítéssel végezteti a mozgást, ez a ritmikus intendálás. Nemcsak mondják hangosan és felkészülnek a mozgásra, de a konduktor mutatja is, a betegek tehát tudatosan, auditív és vizuális módon kapják a megerősítést. Ugyanakkor látják a szomszédaik mozgását is. Tehát egyidejűleg többoldalú megerősítést kapnak.

A közösségi munkában az egyénnek nem túlzott a felelőssége, mert ha kórusban mondanak például egy verset, és két-három szót nem tud valaki, az eltünik a tömegben. Tehát nem izgul, felveszi a fonalat esetleg két sorral odébb, semmi baj. Következő alkalommal megint kórusban mondják, akkor már tudni fogja. Mivel a gyerekek csoportosan (10-15 fó) egyszerre végzik a feladatokat, egyikben sincs drukk, hogy most őt nézik, jól csinálja-e vagy sem. Ez a csoportos munka ily módon oldja a feszültséget” [2].

\section{A gyógyító pedagógia gyökerei, a tudástranszfer}

A gyógyító-nevelő módszerek az emberközpontú reneszánsz korban alakultak ki. A kor embere már hitt a rendszeres nevelés hatásában, különösen a fogyatékosok esetében. A nevelés alapkövetelménye a szigorú fegyelmezés, szorgalmas gyakoroltatás, erényekre való szoktatás volt a túlzott megterhelés mellőzésével. Sok neves humanista tudós foglalkozott a problémával: Rudolf Agricola, Juan Pablo Bonet, Hieronymus Cardanus, Ramírez de Carrión, Desiderius Erasmus, Mercurius van Helmont, Martin Luther, Hieronymus Mercurialis, Paracelsus, Francesco Petrarca, Pedro Ponce de León stb. $[2,14]$.
A gyógyító pedagógia az a határterület, amely két tudományterületet egyesít: a gyógyítást mint célt és a pedagógiát mint a módszer eszközét. A későbbi gondolkodók folytatták az elméleti kidolgozást. Ezek részben a filozófiára épültek, de a két tudományág szegregált területeit is gazdagították. Ebben az időszakban kezdték kidolgozni a hallás- és beszédkárosodottakkal való foglalkozás elméleti részét.

A legkiemelkedőbb, gyógypedagógiával is foglalkozó tudósok közé sorolhatjuk Jan Amos Comenius (15921670) cseh pedagógust, akinek életmúve megreformálta az addigi pedagógiai gyakorlatot, kidolgozta a modern pedagógia alapelveit, a fogyatékosokkal való bánásmódot, melyben nagy szerepet játszik az érzékszervek múködtetése és a türelmes nevelés. Elítélte a divatos testi fenyítést, amelyet nevelőeszközként alkalmaztak.

A XVIII. században nagy változáson ment keresztül mind az oktatás, mind az orvostudomány. Az előbbiben kialakultak az új, állami keretek, ami az egyházi felügyelet részleges megszünését jelentette. Mária Terézia Ratio Educationis rendelete (Bécs, 1777) értékes törekvéseket (például a részlegesen ingyenes oktatást) valósított meg, és közhasznú, gyakorlatias tantárgyakat (például a testnevelést) építtetett be a tantervbe. A fogyatékosok nevelése még egyházi kézben maradt.

Herman Boerhaave, Európa-hírü holland klinikus tanítványa, Gerhard van Swieten (1700-1772), a bécsi udvar orvosa kapta feladatul a magyar egészségügy megszervezését. Megalapította a Nagyszombati Egyetem orvosi fakultását (1769), és megszervezte az ország megyéinek orvosi ellátását (Generale Normativum in Re Sanitatis, 1770), valamint az értelmi fogyatékosok számára intézet alapításának tervét dolgozta ki. Johann Peter Frank (1745-1821) a munkaterápiát szorgalmazta ilyen esetekben, míg Johann Ignaz Felbiger (17241788 ) önálló, az államitól független oktatási tervet készített számukra.

Az ortopédia kifejlődése, a mozgási problémák felismerése és leírása Nicholas Andry (1658-1742) nevéhez füződik $[2,14]$.

Johann Heinrich Pestalozzi (1746-1827) munkássága döntő hatással volt a fogyatékosok intézeti fejlődésére. Elhagyott, hátrányos helyzetű gyerekek számára menhelyet és mintagazdaságot hozott létre. A munkát fontos nevelési eszköznek tekintette, mert az rendszerességet követel, így az oktatás és a munka együttesen formálja a gyermek jellemét. Komplex módszertanát a számolás, mérés, rajzolás és anyanyelvi oktatás alkotta. A fogyatékos gyerekekre is felfigyelt. Érdeklődését egy Mind nevü beteg keltette fel, aki egyetlen kommunikációs csatornáján, a rajzoláson keresztül hívta fel magára a figyelmet. Pető nem véletlenül nevezte intézetét Pestalozzi-ambulanciának.

A francia iskola kimagasló tagja, Jean Gaspard Marie Itard (1775-1838) a gyógypedagógiában két lényeges, új szempontot fedezett fel, miszerint az egyik funkció fejlődése az összes többi javulását elősegíti, és hogy az 
utánzás igen fontos szerepet játszik a tanulási folyamatban $[14,15]$. Következésképpen a képességek és készségek fejlesztése igen lényeges a „fiziológiás nevelési módszer" kialakításában. Itard tanítványa, Éduard Seduin (1812-1880) továbbfejlesztette mestere módszerét:

a) a tudatos nevelést a lehető legkorábban, az intézeti kor előtti időszakban kell elkezdeni, tehát már az anyát kell megtanítani az otthoni gyógyító nevelésre; ezt nevezzük ma korai fejlesztésnek;

b) fontos szempont, hogy a tanítás változatos, az életrend egyénre szabott legyen, míg a közös munka és a célzott játék ne legyen teljesítményorientált, hanem maga a tevékenység legyen a cél;

c) bebizonyította: nincs reménytelen eset, módszerei révén minden fogyatékos értelmi képessége fejleszthető $[14,15]$.

Mindhárom felismerés Pető módszerének alkotóelemét képezi.

A XIX. század elején Ausztriában és Svájcban intézetek jöttek létre értelmi fogyatékos gyerekek számára. Haladást jelentett, hogy a tanulóknak tanrendet alakítottak ki. Johann Jacob Guggenbühl (1816-1863) Abendbergi Intézete kórház és iskola együttese, ahol ez volt az első gyakorlat, amelyben az orvos és a pedagógus egyszerre foglalkozik a gyerekekkel; gyógyszeres kezelés mellett a szabadban végeztetett testedzést. Hangsúlyt fektetett az érzékszervek gyakoroltatására és a kisgyermekkori beszédtanításra, amit ritmusnevelés segítségével végzett. Természetesen Itard és Guggenbühl egyaránt igen ellenséges és provokatív társadalmi légkörben dolgozott: környezetük nem tudta elviselni rendhagyó, újító szándékukat [16].

A mozgás és a ritmus a XX. század elején már nemcsak a beteg emberek állapotának javítására szolgált, hanem fontos szerepet töltött be, és népszerűvé váltak az életreform-mozgalmak, amelyek a vezető értelmiségi körökben termékeny talajra hullottak. Az életmód megreformálásába egyaránt beletartozott a helyes táplálkozás, a mozgás, a természet közel hozása a mindennapi élethez, a férfi-nő kapcsolat újraértelmezése, vagyis a nők aktív társadalmi szerepvállalásának igénye, a gyermek társadalmi helyének megváltozása, a nevelés és az oktatás megreformálása. Természetesen mindezzel együtt új ideológiák is születtek, forradalmasították az iskolai oktatást - nagy társadalmi vitákkal -, aminek eredményeként lassan, de elfogadottá vált az új típusú reformpedagógia elveit valló iskolák létrehozása, mint például a mozgásmúvészeti, a Waldorf-féle vagy a sokkal később alapított Kodály-iskolák; ezek eredményei alkotóelemként megtalálhatók a Pető-féle iskolánál is.

Rudolf Steinerről (1861-1925), korának kiváló fizikusáról a maga idejében sok szó esett az európai fóvárosok szalonjaiban, kávéházaiban. Steiner kezdetben anarchista volt. Később a teozófiához közel álló tudós, aki megalapította az antropozófiát. Steinert a svájci Waldorf-Astor cigerattagyár igazgatója felkérte, hogy a munkások gyermekei részére dolgozza ki az elképzelt legjobb, modern pedagógiai módszert, és valósítsa meg a később Waldorf néven híressé vált, ma is múködő iskolarendszerét.

Steiner alapfilozófiája, hogy nemcsak az intellektust akarta képezni és fejleszteni, hanem az egész embert, érzelmi és fizikai képességeivel együtt. Gondolkodásába beolvasztotta a keleti kultúrák emberismeretét, a test-lélek-szellem egymásra hatását. E hármas kapcsolatot úgy képzelte el, mint a koncentrikus köríveket: középen az emberi test-testiség, a következő kör az érzékelés és indulatok, a harmadik az individuum $[2,14]$. Módszere az ősi kínai, indiai filozófia és orvoslás történetéből és az arisztotelészi filozófiából táplálkozott, hozzákapcsolva a modern pszichológiát, orvostudományt és pedagógiát.

A Waldorf-iskola 1919-ben indult; koedukált rendszere akkor még nem volt elfogadott. A 12 évfolyamos oktatás első nyolc éve a legfontosabb személyre, a pedagógusra épült. Nem a szaktárgyi tudás volt a lényeg, hanem a gyerekekkel való személyes, stabil kapcsolat kialakítása és a pszichológiai önismeret fejlesztése. Fontos szerepet kapott a múvészet: ének, zene és hangszer (furulya) oktatása, valamint a múvészi torna. Véleménye szerint a zenei érzék minden emberben benne él, csak vagy elfojtott állapotban marad, vagy sikerül felszínre hozni. Meggyőződése Kodály hitvallásával azonos: nincs botfülü gyerek, mind alkalmas arra, hogy zenéljen, és érezze a ritmust. És mert érzelmeket tudnak kifejezni múvészettel, ezért a szív iskolája; mert fafaragást, kovácsolást, agyag-és fémmunkát, földmérést tanulnak, ezért a kéz iskolája; mert az egyes tantárgyakat napi több órán át, koncentráltan oktatják, ezért a fej iskolája.

Steiner a filozófiájával és pedagógiai módszerével nagy hatást gyakorolt magyar pedagógus kortársaira, mint például Török Sándorra, továbbá pszichológusokra és oktatási szakemberekre. Elsősorban Petőre, aki behatóan tanulmányozta Steiner írásait, és hetente többször konzultált erről Török Sándorral [2, 14].

Pető a módszerét konduktív pedagógiának nevezte. Hogy miért és hogyan, arról az első főkonduktor, Székely Ilona a következőket mondja:

- Sokszor úgynevezett bemutató foglalkozásokat tartott. Ezeken ő maga adta az új feladatokat a csoportnak, de a segítés módját, az úgynevezett facilitációkat már nekünk kellett kitalálni, hogy úgy segítsünk, mintha nem is segítenénk. A zenészt is belülről kell, hogy vezesse a muzsika, ez a kondukció. Pető intenzíven foglalkozott a képzés formájával, tartalmával, idejével. Elnevezésünk sokszor változott: voltunk mozgásterápiai kezelőnők, gyermekápolónők, de egyik sem fedte azt, amit csináltunk. Kereste a mindentől, mindenkitől elkülöníthető, speciális képzést és elnevezést. Mert a világ nehezen fogadta el, nem is tudta megfogalmazni, mi az, amit csinálunk. Már a külföldiek is érdeklődtek, és még mindig nem volt megfelelő elnevezésünk. A módszer folyton változott. A „helyreállítás” elnevezés Petőnek rettenetes nagy gondot okozott, nehogy gyógytornászoknak gondoljanak minket, s ez veszélyeztesse az intézet függetlenségét. Aztán a gyógyító pedagógia is szóba jött, de ezt is 
elvetette. Lényegében a konduktor egy szakképzett anya, aki irányítja, vezényli gyermeke tevékenységét. Ebben a folyamatban benne foglaltatik az egész tevékenység, amit csináltunk. Mert az anya tanítja meg a gyereket ülni, járni, beszélni, élni. A Pető-módszer szerint ezt a szerepet a konduktor vállalja $[2,14]$.

\section{A Pető-módszer és értékelése}

Barátja, Kun Miklós pszichiáter Pető széles körű beteganyagáról beszél, akiket sikerrel rehabilitált módszere segítségével:

- Biztos vagyok benne, hogy Petőnek nem voltak kétségei afelől, hogy a beteg gyerekeket meggyógyítja. Reggeltől estig gyakoroltatta őket, és sokat tudott rajtuk javítani, még a heine-medineseken vagy a sclerosis multiplexeseken is. Talpra állította óket: fogd meg a széket, és lépj: egy-kettő-három-négy: lépek; egy-kettő-három-négy, hozzálépek; újra: egy-kettő-három-négy: lépek. És ez ment reggeltől estig. Ezek a gyerekek nagyon fáradtak lettek délre a konduktorokkal együtt, de délután, pihenés után kezdtek újra. Kegyetlen munka volt, de hatásos $[2,14]$.

Anyagi szolgáltatást, vagyis pénzt sose fogadott el a betegektől. Pető mindenkivel hajlandó volt foglalkozni, akár volt pénze, akár nem. Volt, akit meg tudott gyógyítani, volt, akit nem.

Petốt az orvostársadalom nagy része nem tartotta eléggé orvosnak, az akkori úgynevezett elit nyugati orvoslás és gyógymódok megválasztása szerint megfelelő gyógyszer vagy agresszív-invazív beavatkozás volt általános. Mindig voltak felkapott eljárások és gyógyszerek, amelyekről aztán későbbi kutatások, retrospektív vizsgálatok szerint kiderült, mégsem az egyetlen orákulum a gyógyításban. Ma nagy divat lett a személyre szabott terápia. Ez az az új módszer? Hogyan másképp lehet gyógyítani, ha nem személyre szabva? A kutatások során kialakulnak elvek, módszerek, eredmények, de az nem alkalmazható mindig mindenkire. A Pető-módszerben is különböző betegségek következtében kialakuló mozgássérülés utáni különböző izomcsoportok múködtetésére speciálisan kialakított rehabilitációs mozgássorok, hozzá ritmus, szöveg, vers, tudati munka párosult.

A Pető-módszer, mint az előzőekben látható, sokféle alapos megfigyelés és empíria alapján folyamatosan változva alakult ki, hiszen a központi idegrendszer elváltozásai miatt kialakult mozgáskorlátozottság vagy bénultság kóroki felfedezése még több területen váratott magára Pető idejében. A személyiségfejlesztés segítségével az addig nem múködő funkciók helyett a tudatos és begyakorolt helyettesítő múködési stratégiát alakította ki a ritmusos intendálás segítségével. Épp ezért nehéz volt meghatározni, hova is tartozik ez a kezelési mód, orvosi, vagy pedagógiai szakterülethez, illetve „szakfelügyelet” alá.

Ebbe persze beleszólt sokféle érdek érvényesítése, nemcsak az elitnek hitt orvostudomány, hanem az aktu- ális politika és fóleg a politikai kapcsolatok, ki hogyan tudta és akarta Petőt és módszerét a folyamatos kirekesztés ellenére megvédeni, vagy személyes érdekek alapján, kinek volt akkor magának vagy családjának valami sérülése vagy problémája a mozgásszerveivel, hiszen ez ma sincs másképp. Így került különböző érdekek szerveződése mentén a pedagógia, vagyis az oktatás területére, kezdetben mozgásterápiai osztályként mint a Gyógypedagógiai Nevelőintézet Kísérleti Mozgásterápiai Osztálya 1945-ben, Pető vezetésével, Bárczi Gusztáv támogatásával. Sikeres eredményei után 1945-50-ig elérte, hogy 1950-ben Országos Mozgásterápiai Intézetté vált, ahol bejáró és bentlakó betegekkel foglalkozott, a Népjóléti, majd később az Egészségügyi Minisztérium felügyeletével. Ahogy a módszer egyre finomodott, igény lett arra, hogy képzőhellyé váljon a bentlakó gyerekek számára - ami nemcsak rehabilitációjukat segíti elő, hanem későbbi társadalmi reintegrációjukat is. Így történhetett például, hogy az intézetben folyó iskolai és iskolán kívüli oktatás eredményeként néhány kiváló orvos, tanár, zeneesztéta, értelmiségi ember vált az intézeti gyerekekből. Bevezette Pető - miután a ritmus, a mondóka az alapeleme a kezelésnek (ritmusos intendálás) - a rendszeres operalátogatást. Elvitte a gyerekeket az Operába, a zenehallgatás, -értés, megszeretése céljából, ami nevelésének egyik fontos része. A proszcéniumpáholy a Petőgyerekeké volt, és az előadások szüneteiben Vaszy Viktor (Kodály tanítványa), az Operaház akkori karmestere felment a gyerekekhez, és a zenéról beszélt nekik, mint ahogy később Lukin László tette a legifjabb zenehallgatókkal.

A leírt sok összetevő, olykor egymásnak ellentmondó tényezők érthetôvé teszik Pető és módszerének besorolhatatlanságát az akkori rigid rendszerekbe. Ehhez társult Pető jelleme, a társadalmi konvenciók teljes figyelmen kívül hagyása, mogorva, bezárkózó, kritizáló és kritikáját azonnal megmondó tulajdonsága. Ingerli és bosszantja az üres fecsegés, a butaság és a tudatlanság. Radnóti Fanni például így ír Naplójában első találkozásukról: „Egy Buddha-pofájú gyanús idegen fogad, nem néz a szemembe a bemutatkozásnál, kellemetlen, undorító alak, ez Pető dr." [17]. Viszont akit szeretett Pető, azzal messzemenőkig figyelmes és odaadó volt. Fizetésének nagy részét támogatásként osztotta szét rászorultaknak. A gyerekekkel való foglalkozásban lelte nagy örömét. Szigorú volt a munkatársakkal, megkövetelte pont azt és annyit, amit és amennyit ő tett: a teljes odaadást.

Tehát sem viselkedésében, sem szakmai szempontból nem tudott belesimulni abba a rendszerbe, amelyik éppen akkor volt mind az egyetemen, mind a nagypolitikában, és mégis mindenki respektálta, sőt elismerte tudását és eredményeit.

Ezért volt oly rögös az útja, ám voltak feltétlen hívei is megrögzött ellenségei mellett. Minden erejét arra összpontosította, hogy intézete teljesen független legyen. Ezért bevetette minden kapcsolatát. Az intézet növekedésének elismeréséül kapott állami segítséggel (Ortutay 
és Biszku támogatásával) új épület jöhetett létre a Kútvölgyi úton. Bár nem ideális a mozgássérültek és a szülők számára, de a hely (genius loci) mutatja, hogy a legmagasabb állami támogatás volt a háttérben az elit pártkórház mellett. Az építkezés egyik heves vitájának következtében, munka közben, akut agyi katasztrófában halt meg 1967. szeptember 11-én.

Pető a módszerében igénybe vette az összes használható évezredes megfigyelések és holisztikus gyógymódok eredményeit, a korai fejlesztés módszereit, a pszichológia addigi eredményeit, a korszerű táplálkozás és izommúködés összefüggéseinek vonzatait, a betegeket bevonta a saját életmódjuk megváltoztatásába, valamint alkalmazta a neurofiziológiai kutatások eredményeit (Pavlov és Luria kutatásain túl), a gyógyítás széles skáláját. Korszakalkotó volt a korai fejlesztés bevezetésében a szülők bevonása, az életmóddá tett terápia, s így nem véletlen, hogy Pető forradalmi - az akkori szemlélet szerint „anarchista” - elmélete alapján kidolgozott módszere egyedi lett.

Az 1985. április 16-án felavatott Kútvölgyi úti intézet felvette megalapítója nevét. Szentágothai János akadémikus a beszédében többek között ezeket mondta:

„Mély benyomást gyakorolt rám, amit én az intézetben látogatásaim során tapasztaltam, és ami olyan ellentétben állt, meglepő ellentétben látszott állani azzal, amit nekünk az orvostudományban a neurológiával kapcsolatban tanítottak. Szinte megdöbbenéssel tapasztaltam, hogy a funkciók csodálatos reorganizációja, rehabilitációja létrejön magától is... hogy az idegrendszer sokkal többet tud, mint amit tulajdonképpen feltételeztünk róla. De éppen ezek az eredmények, amelyeket ebben az intézetben láttam, győztek meg arról, hogy igenis az a módszer, amelyet Pető annak idején kigondolt, amelyiknek fanatikus híve volt, és amelyet nagy meggyőződéssel hirdetett, s nagyon sok ellenállással szemben próbált továbbfejleszteni, és nagy nemzetközi sikerrel juttatott érvényre, hogy ebben minden orvosi megítélés ellenére sokkal több lehetőség van.

Az a nagy pedagógiai igyekezet, elkötelezettség, amit itt a kiképzett vezetők el tudnak érni olyan súlyos eseteknél is, amikor az ember azt mondaná, hogy inkább hagyatkozzunk a modern technológiára, amely életmódbeli könnyítést tud adni a mozgássérülteknek... azt hiszem, nem is lenne helyes a komputerizált, robot ápolóberendezés, gombnyomásra múködő önjáró székek, ágyak irányába keresni a kibontakozást. A kibontakozás ott van, hogy szisztematikus foglalkozással csodálatos eredményeket lehet elérni. Ezek az eredmények nagyon sok esetben tudományosan nem tekinthetők át, nem érthetôk teljesen részleteiben, azonban mindig arra kell gondolnunk, hogy amennyiben a központi idegrendszerben még összeköttetés egyáltalán létezik, akkor a funkció bizonyos mértékig csodálatosan helyreáll. Ezt azonban csak óriási munkával, rendkívüli lelkesedéssel mind a beteg, mind az oktató részéről, állandó gyakorlattal, állandó szinten tartással és a szintek növelésével lehet elérni.
... Meg vagyok győződve, hogy a foglalkozás nem jótékonykodás, hanem a társadalom érdekében való tevékenység, elsősorban azért is, mert egy mozgáskorlátozott, illetve egy rehabilitált mozgássérült tulajdonképpen jobb munkaerő, mint az egészséges, aki magától értetődőnek veszi az életnek ezt az ajándékát. De az, aki nehéz munkával jut el egy teljesítményszintre, ezt olyan nagy értéknek fogja tartani, hogy mindig jobban motivált tagja lesz dolgozó társadalmunknak. Ez az oktatási, pedagógiai rendszerünk diadalmas kezdeményezése, amelynek eredményei máris megvannak, de amelyek most fognak igazán kibontakozni” [1].

\section{Összegzés}

Pető András - a XX. század folyamatos embertelen politikai Közép-Európájában - a hazai szakmai viták ellenére létrehozta az emberi humánum egy olyan gyógyító módszerét, amely ma már mint hungarikum elismert és hatékony kezelés világszerte.

Szentágothai az avatóbeszédében összegzi Pető alkotó, gyógyító tevékenységét. Rögzíti, hogy a tudomány akkori állása és a mai sem tart ott, hogy birtokában legyünk az agyi tevékenységek teljes ismeretének, de érthető, magyarázható és tanulható lehet egyes funkciók speciális javítása. Elismeri, hogy bizonyos kiesett funkciókat más területek átvehetnek és múködtethetnek. Értékeli továbbá a gyakorlás, az új reflexpályák kialakításának és begyakorlásának nehéz feladatát, melyben nagy szerepet játszik a megfelelő gyakorlatok kiválasztása, a gyakoriság, a korai fejlesztés, a kitartó munka, az emberi kapcsolatok, kötődések fontos léte a gyakorlás során, a képesség fejlesztése arra, hogy a páciens rehabilitálódjon mozgásában abból a célból, hogy a mindennapi életében és a társadalomban képes legyen reintegrálódni úgy, hogy önellátó, hasznos munkaerő váljék belőle.

Pető meghatározó személyisége még ma is átsüt a volt munkatársakon, azok gyerekein - a második generáción -, akik a konduktív pedagógia elkötelezett szakemberei lettek, a betegeken, kezelteken, akik Pető nagy hatású, karizmatikus szellemével gyógyulnak, mert Pető a munkáját komolyan vette. Egyik kedvenc tanítványának, Popper Péter pszichológusnak beszélt a dolgok komolyságáról: „Ami fontos és komoly dolog, azt nem lehet kicsit csinálni. Az ember nem lehet kicsit terhes, egy kicsit vérbajos, kicsit halott. Nincs kicsit!” Ez az elhatározottság süt át a mai napig a munkatársak munkájában és a betegek gyógyulni vágyásában. Módszerének egyik alapköve az elkötelezettség, az akarás mind a konduktorok, mind a betegek részéről. Így segíti elő betegei, kezeltjei habitusát, önértékelését, a világhoz való kötődésüket is ez a szemlélet hatja át.

Saját példámon szeretném igazolni a tényét előbbi megállapításaimnak. Pár éve egy mozgássérült-közösségben tartottam előadást, mindenki kerekes székben ült, és kicsit késve nyílt az ajtó: egy fiatal pár minden segédeszköz nélkül, nagyon nehézkes, lassú, dobáló járással meg- 
érkezett, majd leültek egy ott lévő pamlagra egyenes háttal, büszke tartással a csoportba. Egyedül nekik nem volt kerekes székük. Köszöntöttem őket, és önkéntelenül kérdeztem: „Ugye ti petösök (Petö-módszer szerint kezeltek / Petö-intézetiek) vagytok?” Mire visszakérdeztek csodálkozva: „Ezt honnan tudja?” „A tartásotokból és onnan, hogy eszközök nélkül, önállóan jártok saját belsó erôtökre támaszkodva.” Ez Pető szellemisége a XXI. században.

Különböző szakmapolitikai okoknál fogva a Semmelweis Egyetem 2017-ben integrálta a nagy oktatáspolitikai martaléknak tekintett intézetet, akkori hivatalos nevén Egységes Konduktív Pedagógiai Módszertani Intézetet, amely fóiskolai besorolásban volt. Az integrálás eredményeként végre visszatért a medicinális szférába, amely Pető idejében elutasította, és visszakapta alapítójának nevét is, így lett önálló Pető András Kar. A Semmelweis Egyetem büszke lehet mindarra, amit Pető alkotott, és amit utódai megőriztek, továbbfejlesztettek, amit elsősorban kiemelt tanítványa és első utódja, dr. Hári Mária, majd sorban az elkötelezett vezetők, oktatók, személyzet és az őket támogatók, míg ma dr. Tenk Miklósné dr. Zsebe Andrea dékán asszony, a Kar vezetője tett a fennmaradás érdekében. Ám a Pető András Kar is sokat profitálhat az egyetemi családba tartozással, tovább lehet fejleszteni, kitágítani azokat a laboratóriumi, idegélettani kutatásokat, megfelelő orvostudományi elvekkel és teóriákkal, módszerekkel, amelyek segítenek megérteni mélyebben és jobban a módszer múködésének eddig fel nem tárt tudományos hátterét.

\section{Irodalom}

[1] Hári M. History of conductive pedagogy. [A konduktív pedagógia története.] Mozgássérültek Pető András Nevelóképző és Nevelőintézete, Budapest, 1997. [Hungarian]

[2] Forrai J. Memoirs of the beginnings of conductive pedagogy and András Pető. Új Aranyhíd, Budapest and Foundation of Conductive Education, Birmingham, 1999.

[3] Moreno JL. Das Stegreiftheater. [The theater of spontaneity.] Kiepenheuer Verlag, Berlin-Potsdam, 1923.
[4] Pintér G. András Pető and Jacob Levi Moreno. Conductive Education Occasional Papers 2003; 10: 1-12.

[5] Tóthné Szónyi Zs. The chronicles of Narnia in conductive pedagogy. [A Narnia krónikái a konduktív pedagógiában.] Új Pedagóg Szle. 2010; 165-167. [Hungarian]

[6] Charcot JM. Lectures on the diseases of the nervous system. [Előadások az idegrendszer betegségeiről.] A Magyar Orvosi Könyvkiadó Társulat Könyvtára, 27. Budapest, 1875. [Hungarian]

[7] Musil R. Man without qualities. [A tulajdonságok nélküli ember.] Európa Kiadó, Budapest, 1977. [Hungarian]

[8] Stekel W. Poetry and neurosis: Contributions to the psychology of the artist and of artistic creative ability. Psychoanal Rev. 1923; 10: $190-208$

[9] Hárs GyP. Tale about the suppressed morality and criminality. [Mese az elfojtott erkölcsiségről és a kriminalitásról.] Iskolakultúra 2003; 13(11): 113-124. [Hungarian]

[10] Kun M, Dear Hilda. A mental physician in the insane twenthieth century. [Kedves Hilda. Egy elmeorvos az elmebeteg huszadik században.] Medicina Könyvkiadó, Budapest, 2004. [Hungarian]

[11] Balogh E, Kozma I. Conductive education for children with neurological diseases. [A konduktív nevelés gyermekneurológiai indikációja.] Ideggyógy Szle 2009; 62: 12-22. [Hungarian]

[12] Kozma I. The special content, quality and structure of conductor training. In: First Conductive Pedagogical World Conference, 1990. [A konduktorképzés speciális tartalma, minősége és struktúrája. In: Első Konduktív Pedagógiai Világkonferencia, 1990.] Mozgássérülttek Pető András Nevelőképző és Nevelőintézete, Budapest, 1990; p. 11. [Hungarian]

[13] Pető A. Conductive motor therapy, as a special healing-pedagogy. [A konduktív mozgásterápia, mint gyógypedagógia.] Gyógypedagógia 1955; 1:15-21. [Hungarian]

[14] Forrai J. History of a special healing method for motor-disordered children: conductive education. Commun Hist Artis Med. 2007; 53(3-4): 69-96.

[15] Gordosné Szabó A. History of healing pedagogy. [A gyógypedagógia története. Jegyzet.] Tankönyvkiadó, Budapest, 1988. [Hungarian]

[16] Kálmán Zs, Könczei Gy. From Taigetos to equal opportunities. [A Taigetosztól az esélyegyenlőségig.] Osiris Kiadó, Budapest, 2002. [Hungarian]

[17] Radnóti Mné Gyarmati F. Diary 1935-1946. [Napló 19351946.] Jaffa Kiadó, Budapest, 2014; Vol. I, p. 459. [Hungarian]

Forrai Judit dr.

\section{„Nincs az a rossz, amiből ne születne jó!" (Voltaire)}

